\title{
STABILITAS ANTOSIANIN JANTUNG PISANG KEPOK (Musa paradisiaca L) TERHADAP CAHAYA SEBAGAI PEWARNA AGAR-AGAR
}

\author{
Anthocyanin Stability of Banana Bract (Musa paradisiaca L) Toward Light for Jelly Colorant \\ Lydia Ninan Lestario, Matius Kristiarso Wibowo Catur Yoga, Augustinus Ignatius Kristijanto \\ Program Studi Kimia, Fakultas Sains dan Matematika, Universitas Kristen Satya Wacana, \\ J1. Diponegoro 52-60 Salatiga 50711 \\ Email: nlestario@gmail.com
}

\begin{abstract}
ABSTRAK
Tujuan dari penelitian ini adalah untuk menentukan larutan pengekstrak jantung pisang kepok yang menghasilkan antosianin tertinggi, menentukan konsentrasi ekstrak jantung pisang kepok dalam agar-agar yang paling disukai panelis, menentukan laju degradasi warna agar-agar dengan pewarna jantung pisang kepok akibat penyinaran pada berbagai intensitas cahaya, dan menentukan intensitas cahaya maksimum yang masih dapat diterima oleh panelis berdasarkan uji hedonik setelah penyinaran. Antosianin jantung pisang kepok diekstraksi menggunakan pelarut asam tartarat, asam sitrat, dan asam asetat. Kadar antosianin diukur dengan metode perbedaan $\mathrm{pH}$. Untuk uji hedonik digunakan agar-agar dengan kadar ekstrak jantung pisang kepok 15\%, 20\%, 25\%, 30\%, 40\% dan $50 \%$. Uji stabilitas warna dilakukan terhadap agar-agar dengan pewarna jantung pisang kepok $25 \%$, dan disinari selama 10 jam dengan intensitas cahaya 780, 1.850, 2.214, dan 10.340 lux. Hasil penelitian menunjukkan bahwa larutan pengekstrak yang menghasilkan antosianin tertinggi adalah asam tartarat. Konsentrasi ekstrak jantung pisang kepok dalam agar-agar yang paling disukai panelis adalah $25 \%$. Laju degradasi warna agar-agar dengan pewarna jantung pisang kepok meningkat seiring dengan meningkatnya intensitas cahaya, dengan nilai k berkisar antara 0,0042 - 0,0096 AU/Jam. Agar-agar dengan pewarna jantung pisang kepok yang disinari dengan intensitas 780-2.214 lux selama 10 jam masih disukai panelis, sedangkan yang disinari dengan intensitas 10.340 sudah tidak disukai panelis.
\end{abstract}

Kata kunci: Antosianin, jantung pisang, agar-agar, intensitas cahaya, laju degradasi warna

\begin{abstract}
The objectives of this study were to determine the solution that could extract highest anthocyanin from banana bract, to determine the concentration of banana bract extract in jelly which preferred best by panelists, to determine color degradation rate in jelly colored with banana bract against light on various light intensity, and to determine the maximum light intensity which could be accepted by the panelists based on the hedonic test. Anthocyanin of banana bract was extracted by tartaric acid, citric acid, and acetate acid. Anthocyanin content of banana bract was measured by $\mathrm{pH}$ differential method. For the hedonic test, jelly with concentration of banana bract $15 \%, 20 \%, 25 \%, 30 \%, 40 \%$ and $50 \%$, were used with 20 panelists. Then jelly with $25 \%$ concentration of banana bract was used for determination of color degradation rate caused by light with the intensity of 780, 1,850, 2,214 dan 10,340 lux. The results showed that the best solution that extracted highest anthocyanin was tartaric acid, the concentration of banana bract extract in jelly that preferred best by panelists was $25 \%$, the color degradation rate was increased along with the increasing of light intensity, with the $\mathrm{k}$ value $0.0042-0.0096 \mathrm{AU} /$ hour. After 10 hours under light with intensity of 780-2,214 lux, the jelly colored with $25 \%$ of banana bract extract was still could be accepted by panelists, whereas under light intensity of 10,340 lux could not be accepted by panelists.
\end{abstract}

Keywords: Anthocyanin, banana bract, jelly, light intensity, color degradation rate 


\section{PENDAHULUAN}

Warna merupakan faktoryang penting dalammenentukan ketertarikan konsumen terhadap suatu produk pangan, oleh sebab itu produsen pangan olahan umumnya menambahkan pewarna ke dalam produknya (Lestario dkk., 2011). Namun selama ini masih banyak dijumpai penyalahgunaan terhadap pewarna makanan, seperti penggunaan pewarna sintetik yang kurang aman bahkan sudah dilarang penggunaanya dalam makanan (Lestario dkk, 2009). Oleh karena itu, perlu dikembangkan penggunaan pewarna alami sebagai pewarna makanan yang aman dengan harga relatif murah (Tensiska dkk., 2007).

Antosianin merupakan salah satu pewarna alami yang dapat dijadikan sebagai pewarna makanan yang aman (Sari, 2008). Pigmen ini termasuk golongan senyawa flavonoid, yang paling tersebar luas dalam tumbuhan, penyebab hampir semua warna merah pada daun, bunga, dan buah pada tumbuhan tingkat tinggi (Harbone, 1996). Menurut DelgadoVargas dan Paredes-Lopez (2003) sejumlah produk makanan diwarnai oleh antosianin, seperti jus, selai, dan soft drink. Tensiska dkk. (2007) mengaplikasikan antosianin dari buah arben sebagai pewarna minuman ringan, sedangkan Dewi (2005) mengaplikasikan antosianin dari bunga rosela sebagai pewarna tape ketan. Antosianin sangat berpotensi, oleh karena itu antosianin perlu dikembangkan sebagai pewarna alami pada produk pangan.

Jantung pisang merupakan salah satu sumber antosianin, hal ini dapat dilihat dari warnanya yang merah keunguan. Beberapa penelitian mengenai kandungan antosianin pada jantung pisang yang pernah dilakukan, antara lain oleh Pazmino-Duran dkk. (2001) yang meneliti kandungan antosianin total jantung pisang kepok sebesar $32 \mathrm{mg}$ antosianin/100 gram bb, Yanuarti (2008) meneliti kandungan antosianin total jantung pisang kepok sebesar 4,67 $\mathrm{mg}$ antosianin/100 gram bb, dan Lestario dkk. (2009) yang meneliti kandungan antosianin total jantung pisang klutuk sebesar 29,66/100 gram dan jantung pisang ambon sebesar 43,74 gram bb.

Pewarna alami dari jantung pisang kepok dapat dimanfaatkan, dengan mengekstrak pigmen antosianinnya guna diaplikasikan pada agar-agar. Hal ini karena agar-agar banyak di jual di pasaran sebagai campuran ronde, dan agaragar disukai oleh anak-anak, namun selama ini banyak agaragar yang diwarnai dengan pewarna sintetik berbahaya seperti Rhodamin-B dan Methanyl Yellow (Dono, 2012).

Sebagai pewarna alami, kestabilan antosianin sangat dipengaruhi oleh $\mathrm{pH}$, suhu, cahaya, oksigen, asam askorbat, gula, enzim dan ion logam (Sari dkk., 2005). Menurut Gintoe (2009) cahaya merupakan salah satu faktor yang paling berpengaruh. Umumnya antosianin lebih stabil dalam kondisi asam, media bebas oksigen dan dalam kondisi suhu dingin dan gelap (Rohmawati, 2007).

Tujuan dari penelitian ini adalah untuk menentukan larutan pengekstrak jantung pisang kepok yang menghasilkan antosianin tertinggi, menentukan konsentrasi ekstrak jantung pisang kepok dalam agar-agar yang paling disukai panelis, menentukan laju degradasi warna agar-agar dengan pewarna jantung pisang kepok pada berbagai intensitas penyinaran lampu fluorescent, dan menentukan intensitas cahaya maksimum, yang masih dapat diterima panelis berdasarkan uji hedonik.

\section{METODE PENELITIAN}

\section{Bahan dan Alat}

Bahan utama digunakan adalah jantung pisang kepok yang didapat dari daerah Salatiga. Bahan-bahan kimia yang digunakan antara lain : $\mathrm{HCl}$, metanol, asam tartarat, asam sitrat, asam asetat (Merck, Jerman), buffer $\mathrm{HCl}-\mathrm{KCl}$ (0,3 M, pH 1), buffer sitrat (0,3M, pH 4,5), kertas Whatman No.1. Bahan untuk membuat agar-agar: tepung agar-agar putih (Swallow Globe), tepung agar-agar merah (Swallow Globe, dengan pewarna Ponceau 4RCI 16255) gula pasir, dan air.

Alat yang digunakan adalah: Spektrofotometer UV-VIS (Mini Shimadzu, 1240), lampu fluorescent 11, 18, 23, 50 watt (Philips, Essential), neraca analitis (Mettler, H80), orbital shaker, dan peralatan gelas.

\section{Pengukuran Antosianin Total}

Pengukuran antosianin total dilakukan dengan metode perbedaan $\mathrm{pH}$ yaitu pada $\mathrm{pH} 1$ dan $\mathrm{pH}$ 4,5 sebagaimana dilakukan oleh Lestario dkk. (2005). Sebanyak 5 gram jantung pisang yang telah dipotong kecil-kecil dimaserasi dengan 30 $\mathrm{ml}$ metanol-HCl 1\% selama semalam dalam suhu dingin, kemudian disaring dan ditampung filtratnya dalam labu ukur $50 \mathrm{ml}$. Setelah itu, residu dibilas dengan pelarut yang sama sebanyak 2x10 ml, dengan orbital shaker selama masingmasing 30 menit (3 ulangan). Filtrat disaring kemudian disatukan dalam labu ukur dan digenapkan dengan pelarut yang sama sampai garis tera. Diambil $0,8 \mathrm{ml}$ ekstrak jantung pisang dan dimasukkan dalam dua tabung reaksi. Tabung pertama ditambah dengan 3,2 ml buffer $\mathrm{pH} 1$ dan tabung kedua ditambah dengan 3,2 $\mathrm{ml}$ buffer $\mathrm{pH} 4,5$. Kedua tabung reaksi didiamkan selama 15 menit, lalu diukur absorbansinya pada panjang gelombang $510 \mathrm{~nm}$ dan $700 \mathrm{~nm}$. Absorbansi yang diperoleh dimasukkan ke dalam rumus:

$$
\mathrm{A}=\left(\mathrm{A}_{510}-\mathrm{A}_{700}\right) \mathrm{pH}_{1}-\left(\mathrm{A}_{510}-\mathrm{A}_{700}\right) \mathrm{pH}_{4,5}
$$


Selanjutnya hasil perhitungan di atas dimasukkan ke dalam hukum Lambert-Beer, yaitu : $\mathrm{A}=\varepsilon$.L.C dengan konsentrasi antosianin dihitung sebagai sianidin-3-rutinosida, dengan koefisien ekstingsi molar sebesar $28.8001 \mathrm{~mol}^{-1} \mathrm{~cm}^{-1}$ dan berat molekul sebesar $445.2 \mathrm{~g}$ (Pazmino-Duran dkk., 2001).

\section{Pengukuran Antosianin Terekstrak dengan Pelarut Organik}

Antosianin terekstrak ditentukan dengan pelarut organic sebagaimana oleh Tensiska dkk. (2007) dengan dimodifikasi. Sebanyak 10 gram jantung pisang yang telah dipotong kecilkecil dimaserasi dengan masing-masing $25 \mathrm{ml}$ asam sitrat $1 \%$, asam tartarat $1 \%$, dan asam asetat $1 \%$ selama semalam dalam suhu dingin, kemudian disaring dan ditampung filtratnya dalam labu ukur $50 \mathrm{ml}$. Setelah itu, residu dimaserasi kembali dengan $15 \mathrm{ml}$ dan $10 \mathrm{ml}$ untuk masing-masing pelarut, dan dilakukan pengadukan dengan orbital shaker selama masingmasing 30 menit. Filtrat disaring kemudian disatukan dan digenapkan dengan masing-masing pelarut sampai garis tera. Diambil $1 \mathrm{ml}$ ekstrak sampel dan dimasukkan dalam dua tabung reaksi. Tabung pertama ditambah dengan $3 \mathrm{ml}$ buffer $\mathrm{pH} 1$ dan tabung kedua ditambah dengan $3 \mathrm{ml}$ buffer $\mathrm{pH}$ 4,5. Masing-masing tabung didiamkan selama 15 menit, lalu diukur absorbansinya pada panjang gelombang $510 \mathrm{~nm}$ dan $700 \mathrm{~nm}$. Jumlah antosianin yang terekstrak dihitung dengan rumus (1).

\section{Penentuan Konsentrasi Asam Tartarat yang Optimum}

Konsentrasi asam tartarat yang optimum untuk ekstraksi mengikuti metode Tensiska dkk. (2007) yang dimodifikasi. Sebanyak 5 gram jantung pisang yang telah dipotong kecilkecil dimaserasi dalam masing-masing $30 \mathrm{ml}$ asam tartarat $2 \%, 4 \%, 6 \%, 8 \%$, dan $10 \%$ selama semalam. Kemudian filtrat disaring dan ditampung dalam labu ukur $50 \mathrm{ml}$. Setelah itu, residu diekstrak lagi dengan 2x10 ml pelarut yang sama, dengan orbital shaker selama 30 menit. Filtrat disaring, kemudian disatukan dalam labu ukur dan digenapkan dengan masing-masing pelarut sampai garis tera. Diambil $2 \mathrm{ml}$ dari masing-masing ekstrak jantung pisang dan dimasukkan dalam dua tabung reaksi. Tabung pertama ditambah dengan $3 \mathrm{ml}$ buffer $\mathrm{pH} 1$ dan tabung kedua ditambah dengan $3 \mathrm{ml}$ buffer $\mathrm{pH} 4,5$. Semua tabung didiamkan selama 15 menit, lalu diukur absorbansinya pada panjang gelombang $510 \mathrm{~nm}$ dan $700 \mathrm{~nm}$. Jumlah antosianin yang terekstrak dihitung dengan rumus (1).

\section{Pembuatan Agar-agar}

10,88 gram tepung agar-agar dimasukkan ke dalam $1400 \mathrm{ml}$ air, dipanaskan hingga mendidih sambil diaduk, lalu ditambah dengan 186,66 gram gula pasir, dan diaduk kembali hingga larut. Setelah semua larut, didinginkan hingga suamsuam kuku, lalu dituang ke dalam wadah plastik bundar transparan $(\mathrm{d}=5 \mathrm{~cm} ; \mathrm{t}=4 \mathrm{~cm})$. Untuk agar-agar dengan pewarna sintetik dibuat sesuai resep dasar, hanya agaragar yang digunakan adalah agar-agar merah. Sedangkan untuk agar-agar dengan pewarna sintetik dengan volume air setengah dari takaran resep, $1400 \mathrm{ml}$ air diganti setengahnya yaitu $700 \mathrm{ml}$ air.

\section{Pembuatan Agar-agar dengan Pewarna Jantung Pisang Kepok 15\%, 20\%, 25\%, 30\%, 40\%, dan $50 \%$}

Agar-agar ekstrak jantung pisang kepok 15\%, 20\%, $25 \%, 30 \%$, 40\%, dan $50 \%$, dibuat sesuai dengan resep dasar, hanya saja $1400 \mathrm{ml}$ air diganti dengan perbandingan antara volume air dan volume ekstrak yang ditambahkan. Untuk lebih jelasnya dapat dilihat pada Tabel 1 .

\section{Uji Hedonik Agar-agar dengan Pewarna Ekstrak Jantung Pisang Kepok dan Agar-agar dengan Pewarna Sintetik (Soekarto, 1985)}

Uji organoleptik dilakukan terhadap parameter warna, aroma, rasa, dan tekstur agar-agar dengan pewarna jantung pisang kepok dengan konsentrasi 15, 20, 25, 30, 40, dan $50 \%$ dan agar-agar dengan pewarna merah sintetik (volume penuh dan volume setengah) dengan dasar uji hedonik. Skala hedonik dibuat lima tingkat, dimulai dari 1 (sangat suka), 2 (suka), 3 (agak suka), 4 (tidak suka), 5 (sangat tidak suka).

Tabel 1. Komposisi bahan untuk pembuatan agar-agar

\begin{tabular}{lcccccc}
\hline \multirow{2}{*}{ Komposisi bahan } & \multicolumn{5}{c}{ Persentase ekstrak jantung pisang yang ditambahkan } \\
\cline { 2 - 6 } & $15 \%$ & $20 \%$ & $25 \%$ & $30 \%$ & $40 \%$ & $50 \%$ \\
\hline Gula $(\mathrm{g})$ & 186,66 & 186,66 & 186,66 & 186,66 & 186,66 & 186,66 \\
Agar-agar $(\mathrm{g})$ & 10,88 & 10,88 & 10,88 & 10,88 & 10,88 & 10,88 \\
Air (ml) & 1190 & 1120 & 1050 & 980 & 840 & 700 \\
Ekstrak jantung pisang (ml) & 210 & 280 & 350 & 420 & 560 & 700 \\
\hline
\end{tabular}


Penentuan Panjang Gelombang yang Menghasilkan Absorbansi Maksimum dari Ekstrak Jantung Pisang Kepok dalam Metanol-HCl 1\%

Ekstrak jantung pisang kepok dengan pelarut metanol$\mathrm{HCl}$ 1\% dimasukkan ke dalam kuvet, kemudian dilakukan scanning panjang gelombang pada daerah 190-900 nm, dengan metanol-HCl 1\% sebagai blanko. Panjang gelombang absorbansi maksimum yang diperoleh, digunakan untuk pengukuran absorbansi stabilitas warna agar-agar.

\section{Pengukuran Stabilitas Warna Agar-agar Ekstrak Jantung Pisang Kepok 25\% (Gintoe, 2009 yang dimodifikasi)}

$50 \mathrm{ml}$ agar-agar ekstrak jantung pisang kepok dimasukkan ke dalam wadah plastik bundar transparan dan ditutup dengan tutup plastik transparan, lalu disinari dengan lampu flourescent dengan intensitas cahaya 780 lux (11watt), 1.850 lux (18 watt), 2.214 lux (23 watt), dan 10.340 lux (50 watt) selama 10 jam. Setiap 2 jam dari setiap perlakuan diambil untuk diukur warnanya. Dari setiap wadah agar-agar diambil 10 gram, dihancurkan lalu dimaserasi dengan $20 \mathrm{ml}$ metanolHCl 1\% selama 1 jam, disaring, filtrat disatukan dalam labu ukur $25 \mathrm{ml}$. Residu dibilas dengan $5 \mathrm{ml}$ pelarut yang sama, kemudian disaring, filtrat disatukan, lalu digenapkan hingga garis tera. Filtrat diukur absorbansinya pada panjang gelombang maksimum ( $=515 \mathrm{~nm}$ ), dengan blanko metanol$\mathrm{HCl} 1 \%$.

\section{Uji Organoleptik Agar-agar dengan Pewarna Ekstrak Jantung Pisang Kepok Setelah Penyinaran (Soekarto, 1985)}

Untuk menentukan pengaruh penyinaran pada agaragar dengan pewarna jantung pisang kepok 25\% terhadap penerimaan panelis, dilakukan uji organoleptik dengan uji hedonik terhadap warna, aroma, rasa, dan tekstur agar-agar setelah disinari lampu dengan intensitas 780 lux, 1.850 lux, 2.214 lux, dan 10.340 lux selama 10 jam, sebagai kontrol digunakan agar-agar tanpa penyinaran. Skala hedonik dibuat lima tingkat, dimulai dari 1 (sangat suka), 2 (suka), 3 (agak suka), 4 (tidak suka), 5 (sangat tidak suka).

\section{Analisis Statistik}

Data stabilitas warna agar-agar dianalisa dengan curvefitting untuk mentukan konstanta laju degradasi, dengan 4 perlakuan dan 6 ulangan. Sebagai perlakuan ialah intensitas penyinaran 780 lux, 1.850 lux, 2.214 lux, dan 10.340 lux, sedang sebagai kelompok adalah waktu analisa. Konstanta laju degradasi dianalisa dengan Rancangan Acak Kelompok (RAK). Untuk membandingkan konstanta laju degradasi warna agar-agar antar perlakuan dilakukan uji Beda Nyata Jujur (BNJ) dengan tingkat kepercayaan $5 \%$.
Data organoleptik dianalisa dengan Rancangan Acak Kelompok (RAK), dengan uji hedonik dengan 20 orang panelis sebagai ulangan. Sebagai perlakuan adalah konsentrasi ekstrak jantung pisang kepok pada agar-agar $(15 \%, 20 \%, 25 \%, 30 \%, 40 \%$, dan $50 \%)$ ditambah dengan pewarna sintetik pada agar-agar dengan volume normal dan volume setengah (jadi ada 8 perlakuan). Uji hedonik dilakukan setelah agar-agar disinari dengan lampu flourescent selama 10 jam dengan intensitas penyinaran 780 lux, 1.850 lux, 2.214 lux, dan 10.340 lux. Purata skor organoleptik antar perlakuan dibandingkan dengan uji Beda Nyata Jujur (BNJ) dengan tingkat kepercayaan $5 \%$.

\section{HASIL DAN PEMBAHASAN}

\section{Kandungan Antosianin Total}

Kandungan antosianin total jantung pisang kepok dari hasil penelitian ini adalah 33,20 $\pm 0,12 \mathrm{mg} / 100 \mathrm{~g}$ berdasarkan berat basah. Hasil penelitian yang lain tentang jantung pisang yang pernah dilakukan antara lain oleh Pazmino-Duran dkk, (2001), antosianin total jantung pisang kepok (32 mg / 100 $\mathrm{g} \mathrm{bb})$ dengan jenis antosianin yang paling dominan adalah sianidin-3-rutinosida. Yanuarti (2008) meneliti kandungan antosianin total jantung pisang kepok (4,67 mg / 100 gram bb). Lestario (2009), meneliti kandungan antosianin total pisang klutuk (29,66 mg / 100 gram bb) dan jantung pisang ambon (43,74 mg / 100 gram bb).

\section{Pengaruh beberapa Macam Pelarut Organik terhadap Jumlah Antosianin Terekstrak}

Hasil uji beberapa macam pelarut organik terhadap jumlah antosianin terekstrak dapat dilihat pada Tabel 2. Asam tartarat menghasilkan antosianin terekstrak yang paling tinggi diikuti oleh pelarut asam sitrat dan asam asetat. Sesuai dengan penelitian yang pernah dilakukan Tensiska dkk. (2007), asam tartarat menghasilkan total antosianin tertinggi dibandingkan dengan asam asetat dan asam sitrat. Hal ini menunjukkan bahwa pelarut asam tartarat merupakan pelarut yang paling baik untuk mengekstrak antosianin dari jantung pisang kepok.

Perbedaan antosianin terekstrak yang dihasilkan untuk setiap jenis asam organik diduga berkaitan erat dengan perbedaan tetapan disosiasi dari masing-masing jenis asam. Asam tartarat memiliki tetapan disosiasi yang lebih besar dibandingkan kedua asam lainnya. Semakin besar tetapan disosiasi semakin kuat suatu asam karena semakin besar jumlah ion hidrogen yang dilepaskan ke dalam larutan. Keadaan yang semakin asam menyebabkan semakin banyak dinding sel vakuola yang pecah sehingga pigmen antosianin semakin banyak yang terekstrak. (Tensiska dkk., 2007). 
Tabel 2. Purata antosianin terekstrak dengan pelarut asam tartarat, sitrat, dan asetat.

\begin{tabular}{lc}
\hline \multirow{2}{*}{ Jenis pelarut } & Antosianin terekstrak $(\mathrm{mg} / 100 \mathrm{~g})$ \\
\cline { 2 - 2 } & $\mathrm{X},- \pm \mathrm{SE}$ \\
\hline Asam tartarat 1\% & $2,45 \pm 0,15$ \\
Asam sitrat $1 \%$ & $0,85 \pm 0,12$ \\
Asam asetat $1 \%$ & $0,33 \pm 0,10$ \\
\hline
\end{tabular}

\section{Pengaruh Konsentrasi Asam Tartarat terhadap Antosianin Jantung Pisang Kepok Terekstrak}

Hasil uji berbagai konsentrasi asam tartarat terhadap antosianin terekstrak dapat dilihat pada Tabel 3. Hasil ini menunjukkan bahwa pada konsentrasi $2 \%-6 \%$ antosianin terekstrak meningkat seiring dengan semakin tingginya konsentrasi asam tartarat, namun kemudian pada konsentrasi $8 \%$ dan $10 \%$ menurun. Hal ini menunjukkan bahwa konsentrasi optimum asam tartarat untuk mengekstrak antosianin jantung pisang kepok terjadi pada konsentrasi $6 \%$. Jadi pelarut asam tartarat $6 \%$ merupakan pelarut yang optimal untuk mengekstrak antosianin jantung pisang kepok. Bila konsentrasi asam tartarat dinaikkan, maka justru akan menurunkan jumlah antosianin terekstrak. Hasil serupa juga diperoleh pada penelitian tentang ekstraksi antosianin dari kulit anggur, konsentrasi optimum asam tartarat untuk mengekstrak antosianin kulit anggur adalah 7,5\%, bila konsentrasi asam tartarat dinaikkan akan menurunkan antosianin terekstrak. Fenomena ini dapat dijelaskan dengan kondisi hipotonik yang terbentuk pada konsentrasi asam tartarat yang rendah, yang menyebabkan penyerapan air oleh sel jantung pisang. Saat konsentrasi asam tartarat meningkat, sel membengkak mencapai maksimum, kemudian pecah, dan mengeluarkan pigmen antosianin ke vakuola. Namun, pada konsentrasi asam tartarat yang tinggi, terjadi keadaan hipertonik, yang menyebabkan sel kehilangan air dan mengeras, dan permeabilitas membran menurun, sehingga sel tidak dapat pecah. Hal ini menyebabkan molekul antosianin tetap di dalam vakuola dan pigmen tidak dapat terekstrak (Spagna, dkk. 2003).

Tabel 3. Purata antosianin terekstrak dengan berbagai konsentrasi asam tartarat

\begin{tabular}{cc}
\hline Konsentrasi asam tartarat & Total antosianin $(\mathrm{mg} / 100 \mathrm{~g})$ \\
\cline { 2 - 2 }$(\%)$ & $\mathrm{X},- \pm \mathrm{SE}$ \\
\hline 2 & $5,18 \pm 0,25$ \\
4 & $10,13 \pm 0,40$ \\
6 & $14,74 \pm 0,40$ \\
8 & $14,65 \pm 0,21$ \\
10 & $14,61 \pm 0,20$ \\
\hline
\end{tabular}

\section{Hasil Uji Hedonik Agar-agar dengan Pewarna Ekstrak Jantung Pisang Kepok dan Pewarna Sintetik}

Hasil uji hedonik agar-agar dengan pewarna ekstrak jantung pisang kepok dan agar-agar dengan pewarna sintetik dapat dilihat pada Tabel 4. Dari segi warna, dapat dilihat bahwa semakin tinggi penambahan ekstrak jantung pisang kepok maka agar-agar semakin disukai oleh panelis, dan juga terlihat adanya perbedaan secara statistik antar perlakuan. Agar-agar dengan pewarna ekstrak jantung pisang kepok $40 \%$ paling disukai panelis dengan skor tingkat kesukaan panelis $1,5 \pm 0.25$ (a). Agar-agar dengan pewarna sintetik setengah dosis, mempunyai skor $1,7 \pm 0,25$ (ab) yang menunjukkan bahwa panelis cenderung lebih menyukai agar-agar yang diwarnai dengan ekstrak jantung pisang $40 \%$. Hal ini menunjukkan bahwa antosianin dari ekstrak jantung pisang kepok mempunyai potensi untuk menggantikan pewarna sintetik. Pewarna sintetik dengan dosis normal justru kurang disukai panelis, hal ini mungkin karena warna merahnya terlalu tua, demikian pula agar-agar dengan ekstrak jantung pisang $50 \%$ juga kurang disukai panelis, karena warna merahnya terlalu tua, sehingga kurang menarik.

Dari sisi aroma, penambahan ekstrak jantung pisang pada berbagai konsentrasi tidak mempengaruhi kesukaan panelis. Hal ini karena penambahan ekstrak jantung pisang pada berbagai konsentrasi tidak menimbulkan perbedaan aroma pada agar-agar yang dapat dikenali oleh panelis. Pada Tabel 4, terlihat bahwa semua perlakuan baik agar-agar yang diwarnai jantung pisang kepok dengan berbagai konsentrasi, maupun agar-agar yang diwarnai dengan pewarna sintetik disukai oleh panelis dengan tingkat kesukaan yang sama.

Dari sisi rasa, hasil uji organoleptik menunjukkan bahwa semakin tinggi konsentrasi ekstrak jantung pisang kepok yang ditambahkan ke dalam agar-agar, semakin tidak disukai panelis. Hal ini diperkirakan karena rasa asam yang ditimbulkan oleh pelarut yang digunakan untuk mengekstrak jantung pisang, semakin tinggi konsentrasi ekstrak jantung pisang kepok yang ditambahkan ke dalam agar-agar, semakin tinggi pula konsentrasi asam tartarat yang terdapat di dalam agar-agar tersebut. Pada konsentrasi ekstrak jantung pisang kepok $15-25 \%$ rasanya masih bisa diterima panelis, yaitu masih termasuk kriteria disukai (skor $=2,56-2,67$ ), namun pada konsentrasi lebih tinggi, tingkat kesukaan panelis menurun ke arah kurang suka, dan tidak suka. Agar-agar dengan pewarna sintetik lebih disukai panelis, karena rasanya tidak asam, karena tidak ada penambahan asam tartarat.

Dari sisi tekstur, hasil uji organoleptik menunjukkann bahwa ada perbedaan antara agar-agar dengan pewarna ekstrak jantung pisang kepok dan agar-agar yang diberi pewarna sintetik. Agar-agar yang diberi pewarna sintetik lebih disukai oleh panelis. Hal ini karena teksur agar-agar 
Tabel 4. Hasil uji hedonik agar-agar dengan pewarna ekstrak jantung pisang kepok dan agar-agar dengan pewarna sintetik sebelum penyinaran

\begin{tabular}{|c|c|c|c|c|c|c|c|c|c|}
\hline \multicolumn{10}{|c|}{ Pewarna sintetik dan persentase ekstrak jantung pisang pada agar-agar } \\
\hline & & $\mathrm{S}_{1 / 2}$ & $\mathrm{~S}$ & $15 \%$ & $20 \%$ & $25 \%$ & $30 \%$ & $40 \%$ & $50 \%$ \\
\hline Warna & $\begin{array}{l}\mathrm{X}^{-} \pm \\
\mathrm{SE} \\
\mathrm{w}=0,59\end{array}$ & $\begin{array}{c}1,7 \pm 0.25 \\
(\mathrm{ab})\end{array}$ & $\begin{array}{c}2,35 \pm 0.29 \\
(\mathrm{bc})\end{array}$ & $\begin{array}{c}3,45 \pm 0,36 \\
\text { (d) }\end{array}$ & $\begin{array}{c}2,7 \pm 0,25 \\
(\mathrm{c})\end{array}$ & $\begin{array}{c}2,7 \pm 0,32 \\
\text { (c) }\end{array}$ & $\begin{array}{c}2,25 \pm 0,28 \\
\text { (bc) }\end{array}$ & $\begin{array}{c}1,5 \pm 0,27 \\
\text { (a) }\end{array}$ & $\begin{array}{c}1,78 \pm 0,48 \\
(\mathrm{ab})\end{array}$ \\
\hline Aroma & $\begin{array}{l}\mathrm{X}^{-} \pm \\
\mathrm{SE} \\
\mathrm{w}=0.62\end{array}$ & $\begin{array}{c}2,05 \pm 0,4 \\
\text { (a) }\end{array}$ & $\begin{array}{c}2,27 \pm 0,35 \\
\text { (a) }\end{array}$ & $\begin{array}{c}2,5 \pm 0,36 \\
\text { (a) }\end{array}$ & $\begin{array}{c}2,33 \pm 0,22 \\
\text { (a) }\end{array}$ & $\begin{array}{c}2,33 \pm 0,27 \\
\text { (a) }\end{array}$ & $\begin{array}{c}2,33 \pm 0,22 \\
\text { (a) }\end{array}$ & $\begin{array}{c}2,5 \pm 0,36 \\
\text { (a) }\end{array}$ & $\begin{array}{c}2,5 \pm 0,36 \\
\text { (a) }\end{array}$ \\
\hline Rasa & $\begin{array}{l}\mathrm{X}^{-} \pm \\
\mathrm{SE} \\
\mathrm{w}=0,79\end{array}$ & $\begin{array}{c}1,56 \pm 0,33 \\
\text { (a) }\end{array}$ & $\begin{array}{c}2 \pm 0,45 \\
(\mathrm{ab})\end{array}$ & $\begin{array}{c}2,56 \pm 0,45 \\
(\mathrm{bc})\end{array}$ & $\begin{array}{c}2,39 \pm 0,36 \\
(\mathrm{bc})\end{array}$ & $\begin{array}{c}2,67 \pm 0,35 \\
\text { (bc) }\end{array}$ & $\begin{array}{c}2,94 \pm 0,29 \\
\text { (cd) }\end{array}$ & $\begin{array}{c}3,44 \pm 0,45 \\
\text { (d) }\end{array}$ & $\begin{array}{c}3,61 \pm 0,42 \\
\text { (d) }\end{array}$ \\
\hline Teksur & $\begin{array}{l}\mathrm{X}^{-} \pm \\
\mathrm{SE} \\
\mathrm{w}=0,58\end{array}$ & $\begin{array}{c}1,39 \pm 0,23 \\
\text { (a) }\end{array}$ & $\begin{array}{c}1,89 \pm 0,35 \\
(\mathrm{ab})\end{array}$ & $\begin{array}{c}2,67 \pm 0,34 \\
\text { (c) }\end{array}$ & $\begin{array}{c}2,94 \pm 0,34 \\
\text { (c) }\end{array}$ & $\begin{array}{c}2,67 \pm 0,35 \\
\text { (c) }\end{array}$ & $\begin{array}{c}2,56 \pm 0,28 \\
\text { (c) }\end{array}$ & $\begin{array}{c}2,39 \pm 0,36 \\
(\mathrm{bc})\end{array}$ & $\begin{array}{c}2,56 \pm 0,33 \\
\text { (c) }\end{array}$ \\
\hline
\end{tabular}

Keterangan: Angka-angka yang diikuti oleh huruf yang sama menunjukkan antar perlakuan tidak berbeda nyata, sedangkan angka yang diikuti yang berbeda menunjukkan antar perlakuan berbeda nyata, dengan tingkat kepercayaan 5\%.

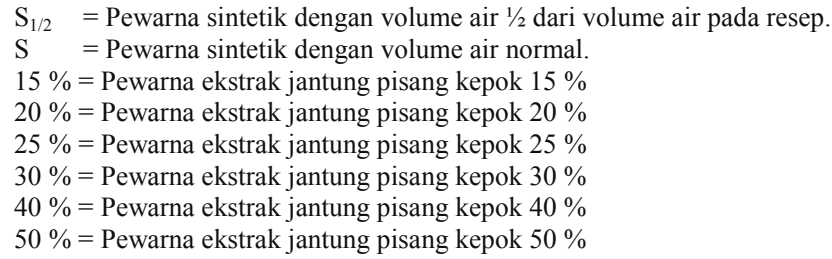

yang diberi pewarna ekstrak jantung pisang kepok lebih lunak dibanding dengan agar-agar yang diberi pewarna sintetik. Nampak bahwa panelis lebih menyukai agar-agar dengan tekstur yang lebih keras daripada agar-agar yang lunak. Hal ini juga terlihat dari data skor uji organoleptik pada agar-agar yang diberi pewarna sintetik, yaitu agar-agar dengan volume air setengah lebih disukai daripada agar-agar dengan volume air normal. Perbedaan berbagai konsentrasi ekstrak jantung pisang tidak mempengaruhi tingkat kesukaan panelis.

Hasil uji organoleptik secara keseluruhan terhadap agar-agar yang meliputi parameter warna, aroma, rasa, dan tekstur, dapat disimpulkan bahwa ekstrak jantung pisang 25 $\%$ merupakan konsentrasi yang paling tepat sebagai pewarna agar-agar. Karena selain warna, aroma, dan teksturnya yang lebih disukai, rasanya juga masih bisa diterima panelis.

\section{Scanning Panjang Gelombang Absorbansi Maksimum}

Scanning panjang gelombang dilakukan untuk mengetahui panjang gelombang yang menghasilkan absorbansi maksimum pada spektra ekstrak jantung pisang kepok dalam pelarut methanol- $\mathrm{HCl} 1 \%$, yang hasilnya digunakan untuk pengukuran absorbansi pada uji degradasi warna agar-agar ekstrak jantung pisang kepok $25 \%$ akibat penyinaran.

Hasil scanning panjang gelombang maksimum menunjukkan ada dua puncak spektra absorbsi, yaitu pada
Skor 1 : sangat suka

Skor 2 : suka

Skor 3 : agak suka

Skor 4 : tidak suka

Skor 5 : sangat tidak suka

panjang gelombang $293 \mathrm{~nm}$ (dengan nilai absorbansi 0,679) dan $515 \mathrm{~nm}$ (dengan nilai absorbansi 0,642). Selanjutnya panjang gelombang $515 \mathrm{~nm}$ digunakan untuk pengukuran absorbansi pada uji degradasi warna agar-agar.

\section{Fotodegradasi Agar-Agar Ekstrak Jantung Pisang Kepok $25 \%$}

Penyinaran terhadap agar-agar yang diberi warna jantung pisang kepok $25 \%$ menyebabkan terjadinya degradasi warna agar-agar yang hasilnya dapat dilihat pada Tabel 5. Agar-agar yang semula berwarna merah menjadi merah pucat bahkan cenderung putih. Hal ini diindikasikan oleh penurunan nilai absorbansi ekstrak dalam pelarut Metanol-HCl 1\% pada panjang gelombang maksimumnya.

Degradasi warna yang terjadi pada agar-agar yang diberi warna ekstrak jantung pisang kepok $25 \%$ mengikuti orde reaksi ke-0 untuk semua perlakuan penyinaran yang artinya laju degradasi sama dengan konstanta laju degradasi.

Pada Tabel 5 terlihat bahwa laju degradasi mengalami peningkatan seiring dengan meningkatnya intensitas cahaya. Hal ini ditunjukkan oleh adanya peningkatan konstanta laju degradasinya (Gambar 1.). Proses penyinaran oleh cahaya lampu fluorescent menyebabkan terjadinya degradasi warna antosianin. Energi yang dihasilkan dari penyinaran dapat menyebabkan terjadinya reaksi fitokimia yang merusak 
struktur antosianin menjadi kalkon yang tidak berwarna (Sari dkk., 2005).

Tabel 5. Konstanta laju degradasi warna agar-agar dengan pewarna ekstrak jantung pisang kepok $25 \%$.

\begin{tabular}{llc}
\hline Intensitas cahaya (Lux) & Konstanta laju degradasi (A.U./Jam) \\
\hline 780 & $0,0042 \pm 0,0006$ & $\mathrm{a}$ \\
1.850 & $0,0043 \pm 0,0007$ & $\mathrm{ab}$ \\
2.214 & $0,0057 \pm 0,0008$ & $\mathrm{~b}$ \\
10.340 & $0,0096 \pm 0,0012$ & $\mathrm{c}$ \\
\hline
\end{tabular}

Keterangan : *Angka-angka yang diikuti oleh huruf yang sama menunjukkan antarperlakuan tidak berbeda secara nyata, sedangkan angkaangka yang diikuti oleh huruf yang berbeda menunjukkan antarperlakuan berbeda secara nyata, dengan tingkat kepercayaan $5 \%$. *Untuk setiap intensitas cahaya diulang 6 kali

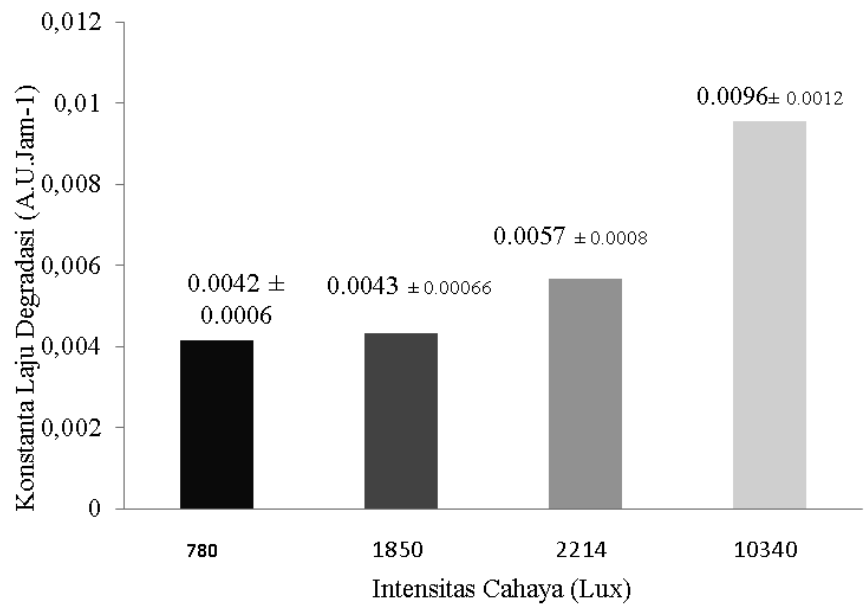

Gambar 1. Histogram hubungan antara intensitas cahaya dan konstanta laju degradasi warna agar-agar dengan pewarna ekstrak jantung pisang kepok $25 \%$

\section{Hasil Uji Hedonik Agar-agar dengan Pewarna Ekstrak Jantung Pisang Kepok Setelah Penyinaran}

Hasil uji hedonik agar-agar yang diwarnai dengan jantung pisang kepok setelah penyinaran dapat dilihat pada Tabel 6, yang menunjukkan bahwa semakin besar intensitas cahaya yang mengenai agar-agar, warna agar-agar semakin pucat, akibatnya tingkat kesukaan panelis semakin berkurang. Hal ini bisa dilihat dari penilaian tingkat kesukaan oleh panelis terhadap warna agar-agar tanpa diberi penyinaran (kontrol), sangat disukai panelis. Agar-agar yang diberi penyinaran dengan intensitas 780 dan 1.850 lux warnanya lebih muda dibanding kontrol, namun masih disukai panelis. Begitu juga agar-agar yang diberi penyinaran 2.214 lux, warnanya lebih muda jika dibandingkan dengan kontrol dan agar-agar yang diberi intensitas cahaya 780 dan 1.850 lux, sehingga agak disukai panelis. Sedangkan penyinaran dengan intensitas cahaya 10.340 lux, menghasilkan warna yang paling pucat sehingga tidak disukai oleh panelis.

Penyinaran tidak mempengaruhi aroma dan rasa agar-agar, panelis menyukai aroma agar-agar untuk semua perlakuan. Sedangkan untuk tekstur agar-agar, ada perbedaan hasil penilaian panelis. Agar-agar yang diberi intensitas cahaya 780-2214 lux, teksturnya masih disukai panelis, agar-agar kontrol agak disukai, dan agar-agar yang diberi penyinaran dengan intensitas 10340 lux tidak disukai panelis. Hal ini diduga karena semakin besar intensitas cahaya yang digunakan, menimbulkan suhu yang semakin tinggi, sehingga agar-agar yang semula teksturnya agak keras (kontrol), menjadi lebih lunak (intensitas 780-2.214 lux), dan akhirnya paling lunak (10.340 lux).

Berdasar hasil uji organoleptik terhadap agar-agar yang meliputi parameter warna, aroma, rasa, dan tekstur,

Tabel 6. Hasil uji hedonik agar-agar dengan pewarna ekstrak jantung pisang kepok $25 \%$ setelah penyinaran

\begin{tabular}{|c|c|c|c|c|c|c|}
\hline \multirow[b]{3}{*}{ Warna } & \multirow[b]{3}{*}{$\begin{array}{l}\mathrm{X},- \pm \mathrm{SE} \\
\mathrm{w}=0,44\end{array}$} & \multicolumn{3}{|c|}{ Intensitas penyinaran } & & \\
\hline & & Kontrol & 780 Lux & 1.850 Lux & 2.214 Lux & 10.340 Lux \\
\hline & & $\begin{array}{c}1,4 \pm 0,22 \\
\text { (a) }\end{array}$ & $\begin{array}{c}2,2 \pm 0,23 \\
\text { (b) }\end{array}$ & $\begin{array}{c}2,5 \pm 0,23 \\
\text { (b) }\end{array}$ & $\begin{array}{c}3,3 \pm 0,32 \\
\text { (c) }\end{array}$ & $\begin{array}{c}4,3 \pm 0,29 \\
\text { (d) }\end{array}$ \\
\hline Aroma & $\begin{array}{l}\mathrm{X},- \pm \mathrm{SE} \\
\mathrm{w}=0,43\end{array}$ & $\begin{array}{c}2,4 \pm 0,22 \\
\text { (a) }\end{array}$ & $\begin{array}{c}2,5 \pm 0,30 \\
\text { (a) }\end{array}$ & $\begin{array}{c}2,45 \pm 0,22 \\
\text { (a) }\end{array}$ & $\begin{array}{c}2,5 \pm 0,23 \\
\text { (a) }\end{array}$ & $\begin{array}{c}2,75 \pm 0,28 \\
\text { (a) }\end{array}$ \\
\hline Rasa & $\begin{array}{l}\mathrm{X},- \pm \mathrm{SE} \\
\mathrm{w}=0,57\end{array}$ & $\begin{array}{c}2,65 \pm 0,29 \\
\text { (a) }\end{array}$ & $\begin{array}{c}2,65 \pm 0,33 \\
\text { (a) }\end{array}$ & $\begin{array}{c}3,05 \pm 0,27 \\
\text { (a) }\end{array}$ & $\begin{array}{c}2,9 \pm 0,40 \\
\text { (a) }\end{array}$ & $\begin{array}{c}3,1 \pm 0,28 \\
\text { (a) }\end{array}$ \\
\hline Tekstur & $\begin{array}{l}\mathrm{X},- \pm \mathrm{SE} \\
\mathrm{w}=0,48\end{array}$ & $\begin{array}{c}2,65 \pm 0,26 \\
\text { (b) }\end{array}$ & $\begin{array}{c}2,2 \pm 0,27 \\
(a b)\end{array}$ & $\begin{array}{c}2,1 \pm 0,28 \\
\text { (a) }\end{array}$ & $\begin{array}{c}2,3 \pm 0,21 \\
(a b)\end{array}$ & $\begin{array}{c}3,2 \pm 0,34 \\
\text { (c) }\end{array}$ \\
\hline Keterangan : & $\begin{array}{l}\text { *Angka-angka yang di } \\
\text { yang berbeda menunjı } \\
\text { Skor } 1: \text { sangat suka } \\
\text { Skor } 2: \text { suka } \\
\text { Skor } 3: \text { agak suka } \\
\text { Skor } 4: \text { tidak suka } \\
\text { Skor } 5 \text { : sangat tidak s }\end{array}$ & $\begin{array}{l}\text { eh huruf yang sar } \\
\text { ntarperlakuan be }\end{array}$ & $\begin{array}{l}\text { nunjukkan antarp } \\
\text { ecara nyata, den }\end{array}$ & $\begin{array}{l}n \text { tidak berbeda } \\
\text { kat kepercayaa }\end{array}$ & rata, sedangkan & ng diikuti oleh hu \\
\hline
\end{tabular}


maka agar-agar dengan penyinaran 780-2.214 lux masih bisa diterima oleh panelis, sedangkan untuk penyinaran dengan intensitas cahaya 10.340 lux tidak disukai oleh panelis.

\section{KESIMPULAN}

Berdasarkan hasil penelitian, dapat disimpulkan bahwa larutan pengekstrak yang menghasilkan antosianin tertinggi adalah asam tartarat, konsentrasi ekstrak jantung pisang kepok sebagai pewarna agar-agar yang paling disukai panelis adalah $25 \%$, laju degradasi warna agar-agar dengan pewarna jantung pisang kepok meningkat seiring dengan meningkatnya intensitas cahaya dengan nilai $\mathrm{k}=0,0042$ - 0,0096 A.U/Jam, dan agar-agar dengan pewarna jantung pisang kepok yang disinari dengan intensitas cahaya 780-2.214 lux masih disukai panelis, sedangkan yang disinari dengan intensitas cahaya 10.340 lux tidak disukai panelis.

\section{DAFTAR PUSTAKA}

Delgado-Vargas, F. dan Paredes-Lopez, O. (2003). Natural Colorants for Food and Nutraceutical Uses. CRC Press LLC, Florida.

Dewi, S.K. (2009). Rosela (Hibiscus sabdariffa L.) sebagai Pewarna Tape Ketan Ditinjau dari Stabilitas Warna, pH, Kandungan Gula Pereduksi dan Alkohol. Skripsi. Program Studi Kimia. Fakultas Sains dan Matematika. Universitas Kristen Satya Wacana, Salatiga.

Dono, N.D. (2012). Zat berbahaya dalam makanan. http:// www.kibar-uk.org/2012/03/09/zat-berbahaya-dalammakanan/ [2 Mei 2012].

Gintoe,H.L.(2009).Pengaruh Penyinaranterhadap Degradasi Warna Ekstrak Bunga Rosela (Hibiscus sabdariffa Linn.) dan Sirup Rosela. Skripsi. Program Studi Kimia. Fakultas Sains dan Matematika. Universitas Kristen Satya Wacana, Salatiga.

Harborne, J.B. (1996). Metode Fitokimia: Penuntun Cara Modern Menganalisis Tumbuhan, Institut Teknologi Bandung, Bandung.

Lestario, L.N., Lukito, D. dan Timotius, K.H. (2009). Kandungan antosianin dan antosianidin dari jantung pisang klutuk (Musa brachycarpa Back) dan pisang ambon (Musa acuminata Colla). Jurnal Teknologi dan Industri Pangan 18(2): 143-148.

Lestario, L.N., Rahyuni, E. dan Timotius, K.H. (2011). Kandungan antosianin dan identifikasi antosianidin dari kulit buah jenitri (Elaeocarpus angustifolius Blume). Agritech 31(2): 93-101.
Lestario, L.N., Suparmo, Raharjo, S. dan Tranggono. (2005). Perubahan aktivitas antioksidan dan polifenol pada beberapa tingkat kemasakan buah duwet (Syzygium cumini). Agritech 25(4): 169-172.

Pazmino-Duran, E.A., Giusti, M.M., Wrolstad, R.E. dan Gloria, M.B.A. (2001). Anthocyanins from banana bracts (Musa paradisiaca) as potential food colorant. Food Chemistry 73: 327-332.

Rohmawati, N. (2007). Uji stabilitas pigmen antosianin bunga kana (Canna coccinea Mill.) merah (pengaruh: pemanasan, cahaya, oksidator-reduktor, logam, dan kondisi simpan Berbeda). http://digilib.umm.ac.id/gdl. php? $\bmod =$ browse \&op=read\&id=jiptummpp-gdl-s 1 2007-nanikrohma. [9 Agustus 2010].

Sari, P. (2008). Antosianin buah buni (Antidesma bunius). http://www.foodreview.biz/login/preview. php?view\&id=55742. [11 Agustus 2010].

Sari, P., Agustina, F., Komar, M., Unus, Fauzi, M. dan Lindriati, T. (2005). Ekstraksi dan stabilitas antosianin dari kulit buah duwet (Syzygium cumini). Jurnal Teknologi dan Industri Pangan 16(2): 142-150.

Spagna, G., Barbagallo, R,N., Todaro, A., Durante, M.J. dan Pifferi, G. (2003). A method for anthocyanin extraction from fresh grape skin. Italian Jurnal of Food Science 5(3): 337-346.

Soekarto, S.T. (1985). Penilaian Organoleptik untuk Industri Pangan dan Hasil Industri Pertanian. Bharata Karya Aksara, Jakarta.

Tensiska, Sofiah, B.D. dan Wijaya, K.A.P. (2007). Aplikasi Ekstrak Pigmen dari Buah Arben (Rubus idaeus (Linn.) Pada Minuman Ringan dan Kestabilannya selama Penyimpanan. Prosiding Seminar Nasional Perhimpunan Ahli Teknologi Pangan Indonesia, hal 880-892.

Tensiska, Sukarminah E, dan Natalia D. (2007). Ekstraksi pewarna alami dari buah arben (Rubus idaeus Linn.) dan aplikasinya pada sistem pangan. Jurnal Teknologi dan Industri Pangan 18(1): 25-31.

Yanuarti, U. (2008). Identifikasi Antosianin Jantung Pisang (Musa paradisca, Linn) Varietas Kepok. Skripsi. Program Studi Kimia. Fakultas Sains dan Matematika. Universitas Kristen Satya Wacana, Salatiga. 